\title{
"A PREFACE IS WRITTEN TO THE PUBLIC": PRINT CENSORSHIP, NOVEL PREFACES, AND THE CONSTRUCTION OF A NEW READING PUBLIC IN LATE-VICTORIAN ENGLAND
}

\section{By Barbara Leckie}

\begin{abstract}
A Preface is written to the Public; a thing I cannot help looking upon as an Enemy, and which I cannot address without feelings of Hostility.
\end{abstract}

-John Keats, The Letters of John Keats, 1814-1821

IN 1818 JOHN KEATS CLAIMS THAT PREFACES are written to the public and that he does not want to participate in this mode of address. In 1837 Thomas Love Peacock notes that his novels had originally appeared without prefaces and that he would have preferred that they remain that way. But, he writes, "an old friend assures me, that to publish a book without a preface is like entering a drawing-room without making a bow" (cited in Grierson 134). In England in the 1880s, however, the novel preface went beyond textual etiquette. It was not only written to the public but it also participated in the debate over competing definitions of the reading public, and it contributed, in turn, to a new configuration of this public.

In this paper I want to focus on four prefaces to novel editions published by Vizetelly \& Co. between 1884, when the new publishing company was formed, and 1887, the year before the only nineteenth-century censorship trial in England to target a literary text. I am interested in the ways in which these prefaces worked to redefine prevailing definitions of the reading public at a time when the reading public was perceived to be dominated by mass readers whose tastes were increasingly difficult either fully to identify or control. ${ }^{1}$ Each of these prefaces, strikingly, situates its challenge to the reading public, either directly or indirectly, in the context of print censorship. And each of these prefaces works, quite visibly, to shape a new public in the context of which print restrictions would no longer be an issue. Indeed, if the public was perceived to be somewhat inscrutable in the period there was, nevertheless, one category of reader - the young female reader - that was very precisely and narrowly defined. The category of the young female reader was used both to dictate print restrictions and to "censor ... young ladies," as Anthony Trollope put it in 1868 (87). ${ }^{2}$ By the time that Henry Vizetelly began Vizetelly \& Co. the connection between the category of the young female reader and print restrictions pertaining to the novel dominated the critical discourse. 
I am interested, then, in a form of censorship that was often understood by reference to abstract or actual figures - the young female reader, the British Matron, "two ladies in the country" - and that worked neither through the force of the law nor through implicit speech constraints that rendered certain thoughts unthinkable and hence unspeakable. ${ }^{3}$ It is a form of censorship that sharpens Mill's reference to "the tyranny of the prevailing opinion and feeling" (6) into something more visible if still abstract (the category of the young female reader) and that conforms to, but does not quite overlap with, Foucault's sense of discipline. ${ }^{4}$ To be sure, the law against obscene libel enabled the production of a category of the young female reader in the context of which print restrictions should be exercised. Formulated in 1868, the Hicklin standard defined "the test of obscenity" in terms of works that may "deprave and corrupt those whose minds are open to such immoral influences, and into whose hands a publication of this sort might fall" (Law 371). In the passage preceding this citation, literary quality is explicitly excluded from consideration and in a later section authorial intention is similarly discounted. The only factors worthy of attention when evaluating obscenity, then, are the content of the work in combination with its anticipated readership. Certainly implicit forms of censorship, in Pierre Bourdieu's or Judith Butler's sense, were also strikingly powerful in this period. But the perceived demand upon novelists that they must always consult an imagined young female reader - their teenage sister or daughter - worked neither within the established legal venue of censorship nor as implicit censorship. It was, rather, a category that could be confronted and contested through cultural debates and it is to these debates and, in particular, the debates over the reading public, that I want to turn.

While the range of strategies available to critics concerned to contest the category of the young female reader cannot be exhaustively listed here, some possible strategies are as follows: 1) one could take issue with the content of the construction of the young female reader. One could argue, for example, that women's reading habits were more sophisticated and intelligent, or at least more varied and difficult to summarize, than the category of the female reader allowed; 2) one could accept the category of the female reader but argue that not all novels should be written for such a limited range of readers. Critics who took this approach sometimes suggested a locked bookshelf where "men's novels" could be kept or special limited circulation journals for men; ${ }^{5} 3$ ) one could accept the category of the young female reader but argue that novel-reading had a positive impact on such readers by instilling knowledge otherwise unavailable to them. This strategy often also involved redefining the "immoral" novel in terms more congenial to print freedom; 4) one could attack ostensible sources of the reliance on the young female reader (the circulating libraries, for example) and suggest other sources (the press, novel reviewers) less inclined to defer to the tastes of the female reader in their analysis of literary value. ${ }^{6}$ This strategy often also involved a critique of the reading practices of the contested source. One approach here might be, for example, to illustrate that Mudie (the proprietor of the period's main lending library and perceived to be responsible for print restrictions) reads like a woman; ${ }^{7} 5$ ) one could attempt to shift the debate from the abstract terrain of cultural discussions to the more institutionally powerful terrain of the law by provoking a censorship trial; and finally, 6) one could take issue with the terms of the debate itself and deny any connection between reading novels and moral, social, or political action.

In the $1880 \mathrm{~s}$, the category of the female reader is so fully entrenched in the print censorship debates that challenges to its content - the first approach above - almost never arise. These discussions may take place elsewhere, in the context of other topics, but the 
content of the category of the female reader (as vulnerable and susceptible to novel reading dangers through her tendency to read with her body and emotions rather than with her mind) remains remarkably stable throughout these debates. Equally unusual are any challenges to the established terms of the debate (the last approach referred to above). ${ }^{8}$ Indeed, two of the books published by Vizetelly \& Co., Madame Bovary and A Mummer's Wife, dramatize the devastating consequences of a woman reading too much. The stories in these two novels at once support the idea of a vulnerable female reader and the connection between reading and undesirable social action (adultery in Madame Bovary, adultery and drunkenness in $A$ Mummer's Wife).

In the absence of a challenge to the content of the category of the female reader or the terms of the debate that presuppose a connection between reading and action, a number of strategies nevertheless remain available to the critic as outlined above. These strategies tend either to operate within the prevailing definition of the female reader to reorient the cultural work it is perceived to perform (strategies 2 and 3 above) or to challenge the social structures (from reading communities to the institutions of the law) responsible for the power accruing to the category of the young female reader (strategies 4 and 5 above). Whether one challenged the work performed by the category of the female reader or the social structure that produced it, the category of the female reader was revised and new reading publics were explored. Michael Warner suggests that "when people address publics, they engage in struggles ... over the conditions that bring them together as a public" (12). Novel prefaces offered one forum through which an author could both address and, in the process, produce a newly-defined reading public. But this process of redefinition did not occur without a struggle. Because the category of the young female reader was crucial to nineteenth-century censorship practices, debates concerned to stabilize or contest such definitions took on a heightened importance during the 1880 s when novelists and critics alike were increasingly bristling in the face of print restrictions.

\section{The Public and the Paratext}

IN THE NOVEL PREFACES I consider below several different constructions of the novel-reading public are presented and debated. Before turning to these prefaces, however, I want briefly to consider questions of readership, theories of the paratext, and the status of other paratexts in Vizetelly productions. Jon Klancher writes that the constituencies of print audiences in the nineteenth century were increasingly unclear and Wilkie Collins's "The Unknown Public," published in 1859, similarly flags this aspect of mass readership. ${ }^{9}$ But the very anxiety produced by the unknown public at the same time testifies to its centrality to print dynamics. It is perhaps in response to this uncertainty that such a commanding picture of one element of the novel reading public is presented: young women. For some writers and cultural commentators, the young female reader was the only relevant reader, for better or worse, of the novel. ${ }^{10}$ The novel, accordingly, had to be tailored to her perceived interests, limitations, and vulnerabilities. As Kate Flint notes, the category of the female reader could be used "as a touchstone against which to place fiction with undesirably explicit sexual content" (13). This comment is, indeed, an understatement; the young female reader was increasingly understood as the marker in the context of which print was regulated as countless novelists, reviewers, and cultural critics acknowledged. George Moore puts it most succinctly when he 
imagines Mudie saying, "I cater for the masses, and the masses are young unmarried women who are supposed to know but one side of life" ("Literature" 21).

Vizetelly, however, imagined a different reading public. When he, with George Moore's encouragement, began publishing inexpensive one-volume editions of English novels and English translations of French novels, he clearly did not "cater for the masses" or "young unmarried women" in the same way that Mudie did. Vizetelly was not reserved, moreover, about his challenge to what Henry James referred to as "the unnatural conditions" of literary production in England ("Nana" 868). In the midst of the controversy over realism and its perceived challenges to prevailing values Vizetelly, for example, did not hesitate to call attention, in the novels' paratexts, to their defiance of relied-upon conventions. He prominently displayed "A Realistic Novel" on the title pages of many novels, for example.

The advertising pages at the beginning and the end of these novels further challenged print conventions by selecting passages that highlighted the edition's refusal to conform to censorship expectations and by reiterating the "realistic," "unabridged," and "unexpurgated" character of other Vizetelly publications. Consider the following excerpt, cited repeatedly in the advertisements pages, from a review of Nana that James published in the Parisian in 1880:

\section{Mr HENRY JAMES On ZOLA'S NOVELS}

A novelist with a system, a passionate conviction, a great plan - incontestable attributes of M. Zola - is not now to be easily found in England or the United States, where the story-teller's art is almost exclusively feminine, is mainly in the hands of timid (even when very accomplished) women, whose acquaintance with life is severely restricted, and who are not conspicuous for general views. The novel, moreover, among ourselves, is almost always addressed to young unmarried ladies, or at least always assumes them to be a large part of the novelist's public.

This fact, to a French story-teller, appears, of course, a damnable restriction, and M. Zola would probably decline to take au sérieux any work produced under such unnatural conditions. (James 868-69)

This quotation combines an established and respected name (Henry James) with a foregrounding of the fact that Zola novels, and by association other novels published by Vizetelly \& Co., flaunt prevailing rules and restrictions dictating the range of novelistic representation. These rules and restrictions, moreover, follow specifically from a too circumscribed female readership. If the target is a reading public defined by "young unmarried ladies," the solution is to contest and dismantle such "unnatural" conditions. The paratextual advertisements for Madame Bovary similarly drew attention to the novel's censorship history. The only information provided on the novel is that it is "prefaced by a note of the proceedings against the author before the 'Tribunal Correctionnel' of Paris."

While these advertisements used print censorship and restriction to capture the interest of readers, they were also careful to work within the terms of the existing debates. Advertising material, for example, was quick to stress the moral aspects of the books in question. The flypiece to The Assommoir included an advertisement for The Ironmaster; or Love and Pride, by George Ohnet which claims that the book "unlike the general run of French novels, 
conveys a sound moral" (n.p.). This emphasis on the moral component of a work was not infrequent. The preface to Daudet's Sappho insists that all of his novels "point a salutary and forcible moral" and that Sappho, in particular, is "a book which every young man may read with profit" (xiv). This delimitation of the reader as male, however, tailors the novel for a different reading public than Mudie's young female readers. The introduction to this novel, for example, includes the following dedication: "FOR MY SONS/WHEN THEY ARE TWENTY YEARS OLD." 11 This appeal both distances the text from female readers and from young, inexperienced readers while emphasizing the novel as an adult and sophisticated text.

Even more than this paratextual material, however, the prefaces work actively to reshape the default reader, the definition of what constitutes morality in the context of fiction, and the role of censorship in the literary field. There has been a great deal of scholarship on prefaces in recent years, most of it situated in the context of deconstruction, in general, and Derrida's elaboration on the liminal text and Genette's on the paratext, in particular. This scholarship has been theoretical, discussing the genre of the preface, the placement of the preface with respect to boundaries between inside the book and outside the book, and the philosophical issues that the "liminal" status of the preface raises. Richard Macksey usefully situates prefaces in the context of "thresholds" or, as he puts it, "the literary and printerly conventions that mediate between the world of publishing and the world of the text" ("Foreword" xvii). Derrida distinguishes prefaces from introductions in a manner that bears on my approach in its emphasis on the history of publication. Prefaces, unlike introductions, "are multiplied from edition to edition and take into account a more empirical historicity; they obey an occasional necessity" (Dissemination 17). ${ }^{12}$

Genette is concerned to provide a taxonomy of prefaces and one category he refers to is the "preface manifesto"; these prefaces "argue for a cause broader than that of a literary genre" (228). ${ }^{13}$ While his definition does not work perfectly for the prefaces I treat here they are not typically manifestos, per se - it does draw attention to the ways in which prefaces can be shaped by social and political "causes." It also points to the way that prefaces, even when they are not manifestos, are part of larger social, institutional, and literary structures. I am interested in the preface as a textual space in which authors can engage questions of representation as they relate to broader social discourses. I will not, then, be focusing on the theoretical studies of prefaces in relation to liminality although my thinking on what authors can do with this space does relate to some of the insights advanced by Derrida and Genette. I want to suggest instead that the 1880 s novel preface works in many ways as an interface between "regulatory mechanisms" in the literary and social field - especially in terms of the construction of categories of readers - and the print freedom that was beginning to be demanded by novelists.

My focus, however, will be on an aspect of the preface that Genette does not discuss in any detail: the preface's construction of a reader. If the category of the female novel reader was a construction produced in a variety of contexts across the Victorian literary field, then this construction could similarly be contested and reshaped by the articulation of convincing alternative versions of the novel reading public. Because prefaces commanded a degree of cultural authority and because they were so closely attached to the novels in question, both spatially and temporally, they were an ideal form through which to pose challenges to the narrow, gendered definitions of the novel reading public to which Henry James, George Moore, and so many others objected. 


\section{Literature Without a Veil: The Vizetelly Edition Novel Prefaces}

\section{1. “Disgusting!": De Amicus' Preface to Zola's The Assommoir (1884)}

THE ENGLISH TRANSLATION OF ZOLA'S L'Assommoir at once announces its challenge to English print conditions and works to conform to the conservative reader's expectations. The cover notes that the novel is translated "without abridgement" and a flypiece inside the novel advertises Zola's other novels in a manner that explicitly stresses the "sound moral" one finds in Zola's work. The excerpt from James's review of Zola's Nana, cited above, is also included here. It is in the preface, however, that one encounters the most concentrated attempt to legitimate at once Zola's works and stress their challenge to social conventions and reading practices. The preface first seeks to establish its authority by describing its author, Signor Edmondo de Amicus, as "one of the most brilliant and powerful of the present generation of Italian writers." De Amicus begins his preface with the description of a reader reading:

\footnotetext{
Once in a railway carriage, I saw a Frenchman, who was reading a book very attentively, exhibit, from time to time, signs of surprise. Suddenly, whilst I was trying to discover the title upon the cover, he exclaimed, 'Oh! this is disgusting!' and put the volume into his valise in the most contemptuous manner. He remained for some moments lost in thought, then re-opened the valise, took up the book again, and began reading. He might have finished a couple of pages, when he suddenly burst out into a hearty laugh, and turning to his companion, said, 'Ah! my dear friend, here is the most marvellous description of a wedding dinner!' Then he resumed his reading, showing plainly that he was enjoying it intensely.

The book was the 'Assommoir,' and that which happened to the Frenchman when perusing it occurs to all who take up the novels of Zola for the first time. You must conquer the first feeling of repugnance; then, whatever may be the final judgment pronounced upon the writer, you are glad to have read his works, and you arrive at the conclusion that you ought to have read them. ${ }^{14}$
}

First, de Amicus presents us with a picture not of a woman reading in the home, but of a very public man - he can be discretely watched by a stranger - reading in a railway car. Second, what de Amicus highlights here is the need for the Zola reader to relearn his novel reading skills. Above all, the reader should not give up when confronted by his initial surprise and disgust. To do so would be to miss the pleasures of a Zola novel: the exactness of the description, the truth of the story. De Amicus watches the man on the train attentively and catalogues his reading responses from surprise to disgust to laughter and enjoyment. He extrapolates from this single story a universal moral: the reading experience of the anonymous man on the train is the response of "us all" when we read Zola. And yet, as I have noted, it is a male reader on the train and de Amicus implies that it is to male readers that he directs his remarks when he writes: "Delicate persons withdraw - that is an understood thing" (vi). While several different reading codes are operating simultaneously, the way in which de Amicus conflates a description of a single anonymous reader with the construction of an ideal Zola reader is nevertheless straightforward. He uses the description of the reader on the train to normalize and validate reading responses that might otherwise be discredited for their incitement of disgust. ${ }^{15}$ De Amicus continues:

After reading Zola's romances it seems as if in all others, even in the truest, there were a veil between the reader and the things described, and there is present to our minds the same difference as exists 
between the representations of human faces on canvas and the reflection of the same faces in a mirror.

It is like finding the truth for the first time. (v-vi)

This passage was often used, alongside the James passage cited above, in subsequent Vizetelly editions to advertise the work of Zola and other naturalists. After offering a lesson in reading, then, de Amicus stresses the realism and truth of Zola's representation and in doing so stresses, as James also stresses, the novel's role as an instrument of knowledge, as a genre that "helps us to know" (James 687). If the first response is disgust, the final outcome is knowledge. De Amicus redefines disgust in positive terms associated with the reading capacities of the reader who is not "delicate." In doing so, he contributes to the articulation of a differently defined and delimited reading public than the default female reader currently dominating the literary field.

\section{The "Vicious" and the "Vulgar": Eleanor Marx-Aveling's Preface to Madame Bovary (1886)}

LIKE DE AMICUS, ELEANOR MARX-AVELING attempts to redefine reading response in her preface to Flaubert's Madame Bovary. Unlike de Amicus, she provides an example of hownot-to-read a novel rather than the model reading outlined above. Her task is challenging because, in many ways, Vizetelly could not have been more controversial in his choice of a novel to translate. Madame Bovary not only provided a still forceful definition of the female novel reader but also was the target of one of the most prominent censorship trials of the nineteenth century.

Marx-Aveling notes that she regrets the need to address the question of censorship. It is necessary, however: "unfortunately there are many persons who, though they have never read the book, hold up their hands in holy horror at the bare mention of its name, and it is incumbent, therefore, that we should see of what the charges consisted" (xi). The language of the preface clearly positions Marx-Aveling: she refers to the "mutilated edition" of Madame Bovary published by Du Camp (xi), she implies that there is not "even the slightest foundation" for the prosecution's claims (ix), that the prosecutor himself is "grotesquely ridiculous" (xi) and a lewd reader of an innocent text (xi-xii), and that the "poor man" is "completely annihilated" by the defence (xiii).

Like so many censorship trials, the trial of Madame Bovary was, among other things, a bid to establish cultural authority for one reading practice over another. In this case, the prosecution upholds morality as the most powerful frame of reference when evaluating a novel and identifies a vulnerable reading community in the context of which the dubious morality of the novel injures. Marx-Aveling cites the prosecution as follows: "And who reads the novels of M. Flaubert? Are they read by men occupying themselves with political or social economy? No! These pages fall into the hands of young girls, sometimes of married women..." (xii-xiii). As I have noted, this concern with the vulnerable female reader was even more a staple of English cultural criticism. Like the prosecution in the Bovary trial, one encounters references to this reader made not only by conservative critics (members of the growing social purity movements, publishers concerned with sales, Mudie's and Smith's circulating libraries, government officials, and so on) but also by many novelists who accepted this limit on their literary production.

What Marx-Aveling's preface provides in summary form, however, is one counter strategy to the prevailing concern with vulnerable readers. Instead of accepting "young 
girls" and "married women" as the readers most ill-equipped to deal with a novel like Madame Bovary, she suggests an alternative. Perhaps, she writes, the problem is not the female reader's competence but rather the reading practice of the prosecutor himself. What Marx-Aveling dramatizes here is a contest over the cultural authority to establish appropriate novel-reading strategies. Marx-Aveling pits Pinard's and the Government of Napoleon the Third's reading practices, and to a lesser extent the editors of the The Revue de Paris, against the reading practices of Senard, the lawyer for the defense, and her own interpretation of the novel. She further implies that now "that English people will have a chance of reading "Madame Bovary' " they will draw the same conclusion" (xi). What is the difference between these two groups of readers? In one case, readers are so blinded by their concern with morality that they misread the novel and see immoral material that is not there; in the other, the reader can appreciate Madame Bovary as "a serious, earnest work" (xi), understand that the book speaks for itself (xiii), and that it is a model of excellent style and acute observation.

Marx-Aveling's most scathing critique is reserved for Pinard. He clearly does not understand the story, she writes, and it is "utterly vulgarized in the telling" (xii). "Needless to say," she continues, "the most innocent expression, the most refined thought, became vicious and coarse when seen through the eyes of this moral gentleman" (xi-xii). Here Pinard's reading practices are represented to resemble the reading practices of the young girls and married women he seeks to protect. First, Marx-Aveling dismantles his credibility by critiquing his intelligence: he does not understand the novel and so he misreads it. Second, this misreading is eroticized: where others might see innocence and refinement Pinard sees viciousness and coarseness. Just as Moore aligned Mudie with the British matron in "Literature at Nurse" - "you yourself are the veritable British matron," he suggested to Mudie (16) - Marx-Aveling aligns Pinard with a feminized reading practice.

Marx-Aveling further maintains that it is not the representation of adultery itself that offends Pinard but rather the style or handling of that representation: "instead of insinuating, Flaubert speaks frankly, honestly, with the call of a doctor describing a disease" (xii). She pits insinuation against honesty and a disingenuous "fig-leaf morality" (xii) against an implied real morality. While Marx-Aveling's language is inflammatory here in terms of the English cultural field - the reference to a doctor and disease invokes the contested field of naturalism it does raise a question that was gaining critical purchase in the period: Is honest literature more moral than insinuating literature or is it less so? For Marx-Aveling, and increasingly for many others, it was the insinuating literature defended by the circulating libraries and read by women that was immoral.

\section{3. “The Bar of Public Opinion”: Moore's Preface to his A Mummer's Wife (1886) $)^{16}$}

GEORGE MOORE WAS THE MOST VOCAL spokesperson in the 1880s against what he called "an illiterate censorship" ("New" 32, "Preface," Piping 13). In the wake of Mudie's refusal to circulate his 1883 A Modern Lover, Moore wrote an impassioned article for the Pall Mall Gazette entitled "A New Censorship of Literature." In this article he expressed his frustration with a state of literary production that enabled "two ladies in the country" ("New" 31), with the aid of Mudie, to dictate print restrictions. This article, however, was also a response to Walter Besant's and Henry James's recent articles on the "art of fiction." It would be impossible to establish the novel as a respected aesthetic form, as both Besant and James in their different ways desired, if "freedom of speech" was not first accomplished, Moore 
argued. Fiction cannot flourish, he wrote, when its range of representation is restricted by the interests of "young girls and widows of sedentary habits" (28). This article provoked a debate in the press, largely sympathetic with Moore's position, which lasted for several weeks.

Several months later Moore returned to the question of censorship with an even sharper and angrier account of the debilitating consequences of circulating libraries on English literary production. "Literature at Nurse, or Circulating Morals" was published in pamphlet form by Vizetelly \& Co. in 1885. The ostensible catalyst for the pamphlet was Mudie's refusal to carry Moore's next novel, A Mummer's Wife, and the library's description of this novel as an "immoral publication" (5). Moore's strategy here was to compare his own novel to other novels circulated by Mudie's and to make a "direct appeal to the public" to judge the case. In the process he both infantilized the novels Mudie's circulated by figuring them as "dolls" of questionable attire, and he feminized Mudie himself by figuring his "motherly arms" rocking his novels/dolls to sleep (18).

If Moore appeals to the public in "Literature at Nurse," in his preface to A Mummer's Wife the following year he claims that the "bar of public opinion" has decided the question of censorship in his favor (ix). Frierson aptly describes A Mummer's Wife as a "Zola novel" written “just after Zola read Madame Bovary” (60), and Moore's preface to his novel suggests a victory for those opposed to print censorship that implicitly extended to the novelists by whom he had been so deeply influenced. Certainly A Mummer's Wife had been well-noticed and well-received and by 1895 the novel was in twenty editions (Frierson 73). Indeed, the final advertising page of "Literature at Nurse" includes excerpts from reviews in the Athanaeum, the Graphic, the Pall Mall Gazette, the Academy, and the Spectator favorably impressed with Moore's novel. For the sixth edition of the novel Moore adds a preface to his novel that takes up again the issues raised in the broader debate.

First, Moore flaunts the commercial and critical success of his novel - "it is obviously a satisfaction to find that five editions of your book have gone off within a year" - and then he adds that the real victory, however, is not this sort of "coarse and commonplace" measure of success but rather that the sixth edition of his novel marks his defeat of the philistine: "my sixth edition, is conclusive proof of the enemy's rout" (ix). For Moore, the question even of whether his book is "well or badly written" pales alongside the enormity of this ideological victory.

He notes further that he did not fight his fight alone and he expresses his "heartfelt thanks" to the many novel reviewers who supported him. "I found them neither purblind, ignorant, stupid, nor cowardly." That the lending libraries "expected to find their ruling supported by the press and their customers is probable; that they now pass defeated from the bar of public opinion is certain" (ix). Moore clearly seeks to position the "public" - here defined in terms of novel reviewers - on his side; in the process, commerce and customers are discounted. As he did in his recent writing on print censorship, then, he pits reviewers against Mudie, endeavors to legitimate and authorize the critical acumen of these reviewers, and contributes, in the process, to a new understanding of the role of the critic.

He concludes by taking up the question of honest vs. insinuating representations raised by Marx-Aveling, and also raised by Moore himself in his earlier writings on censorship. $\mathrm{He}$ privileges "frankness of diction" against "suggestiveness" not only because such frankness continues a long English tradition of "plain speaking" shared by such authors as Marlowe, Shakespeare, Jonson, Wycherley, Congreve, Fielding, Swift, Sterne, Byron, Shelley, and 
Landor but also because it is more, and not less, moral than insinuation and evasion (x). For these reasons, A Mummer's Wife represents not an "innovation" in literature but rather a "return to a more healthy taste than at present prevails in literary expression" (x). In both "Literature at Nurse" and this preface, then, Moore does three things: he distinguishes between the press and circulating library customers and he privileges the judgment of the former over the latter; he redefines the moral novel in terms of its frankness of representation rather than its evasion of taboo topics; and he attempts to redefine the novel reading public to conform with the press evaluation of his novels and his own evaluation of what constitutes a moral novel. By repeating these positions in the preface to A Mummer's Wife, Moore borrows the cultural authority commanded by the novel preface to cement positions expressed elsewhere.

\section{"Literature and Young Girls": George Moore's Preface to Zola's Piping Hot! (1887)}

IF GEORGE MOORE WAS READY to claim a victory of "national importance" in his evasion of print censorship and his displacement of the young female reader as arbiter of novelistic representation in his preface to A Mummer's Wife (ix), in his preface to Zola's Piping Hot!, published a year later, the category of the young female reader is again reigning over novel production and limiting it accordingly. The first eight pages of this preface are devoted to Zola's novel and provide a standard translator's introduction. The last three pages, by contrast, take up the concerns of print censorship that occupied Moore at the time. Moore shifts to this topic by way of reference to the hostile reception to Zola's novel. This hostile reception contrasts markedly with Moore's earlier confidence in the press to adjudicate between competing claims for literary value. He imagines that once books were judged on the basis of "literary merit" but that now a "new school of criticism" prevails that is guided by a single question: can this book be read to one's sixteen-year-old sister? ${ }^{17}$ He stresses a point that he had made almost verbatim in "Literature at Nurse" and that James's made in his review of Zola: "Literature and young girls are irreconcilable elements" (13; "Literature" 21). In "Literature at Nurse" he allowed that young girls "should be provided with a literature to suit their age and taste" but claimed that such a requirement should not cripple the writing range of authors with bolder ambitions (21). He granted that the low price of the one-volume novel made it possible for "a young girl to buy an immoral book":

But even for the alarmed mother, I have a word of consolation. For should her daughter, when our novels are sold for a half-a-crown in a paper cover, become possessed of one written by a member of the school to which I have the honour to belong [naturalism], I will vouch that no unfortunate results are the consequence of the reading. (22)

He further maintained, as he had earlier, that the real danger to young women lay not in naturalist novels but rather in the false and insipid romances promoted by the circulating libraries.

In his preface, however, Moore does not raise the spectre of the young female reader purchasing Zola's book. Rather, he focuses on the role of censorship on English literary production. The system, over all, he claims, produces an "illiterate censorship" (13) that is responsible for the current "abysmal" state of English fiction. He concludes with a clear statement of his own position: 
if fiction is to exist at all, the right to speak as he pleases on politics, morals, and religion must be granted to the writer, ... [the writer] on his side must take cognizance of other readers than sentimental young girls.... Therefore the great literary battle of our day is not to be fought for either realism or romanticism, but for freedom of speech. $(15)^{18}$

This preface, then, is an effort to challenge and redefine prevailing constructions of the novel reading public that are perhaps more entrenched than Moore had previously hoped. For Moore, the battle fought over realism and romanticism is second to the more fundamental battle over freedom of speech that is itself a battle over readership. Confronted by the hostile reception to Zola's works, Moore has lost confidence in the press. Instead of working to authorize the critical reading practice associated with the press, then, he returns to his old attacks on the young female reader - "sentimental young girls" - and on Mudie's power to underwrite their hegemony.

In summary, the paratextual matter and in particular the prefaces to Vizetelly edition novels, challenged prevailing definitions of the reading public in two general ways. First, it challenged the framework of the young female reader. The challenges to the category of the young female reader intimated that the young female reader would in fact profit, rather than be harmed by, bolder representations. The prefaces also challenged the framework of the young female reader by presenting alternative readers and reading practices (by offering a male reader's negotiation and final acceptance of "disgust" as one reading response, for example). Second, the prefaces challenged prevailing definitions of the reading public by confronting the cultural authorities through which the category of the young female reader was constructed and maintained, such as Mudie's and Smith's circulating libraries and legal institutions and trials. Furthermore, they presented cultural authorities better qualified to determine criteria for print restrictions (the press, novel reviewers, the writers of the prefaces themselves).

\section{III. "Literature with a Slight Veil": The Trials (1888-89)}

THE VIZETELLY EDITION PREFACES (and paratextual matter) neither softened their challenge to the prevailing construction of the novel-reading public as young and female nor skirted the censorship histories that many of the novels invoked. They can be read as an effort to both describe and contribute to a new version of the reading public more closely aligned with novel "reviewers" than novel "customers." But what happens to this new reading public? Taken together, it could be argued that the prefaces, and the new public they worked to produce, invited the very censorship trial to which the preface writers, and the public they desired, were so opposed.

The National Vigilance Association (NVA) brought about a debate in parliament on the "gigantic national danger" posed by "demoralizing literature" (352) in May 1888 and succeeded, in November of that year, in bringing Vizetelly before the law, for the publication of Zola's La Terre, under the 1867 Hicklin ruling described earlier. Vizetelly and his supporters were initially pleased by the move because they saw it as an opportunity both to cement publicly the English commitment to free speech and to defeat the Hicklin standard. This victory did not occur. Indeed, the jurors seemed so united in their disgust for Zola's novel (a disgust that was not followed by surprise or appreciation) that they asked not to have excerpts read aloud in court despite the legal requirement to do so. Vizetelly, 
on the dubious advice of his lawyer, changed his "not guilty" plea to "guilty" and the trial was quickly dispatched. He was fined and agreed to withdraw all of his publications from circulation. In 1889 the NVA brought another case against Vizetelly and this time he was sentenced to three months jail time and he died a few months after his release.

By way of closing I want to turn briefly to a pamphlet entitled "Pernicious Literature" published by the NVA in 1889 just before the second trial. This pamphlet, like the prefaces discussed here and Moore's pamphlet "Literature at Nurse," constructs the print censorship debates in a manner congenial to its desired outcome. For both those in favour of some form of print censorship and those opposed to it, the battle was fought over contested definitions of public opinion and constructions of the novel reading public.

In "Pernicious Literature" the NVA sought to re-establish their control over the "bar of public opinion." As William Coote, the association's secretary, recounts in the pamphlet's introduction, a "healthy public opinion" is needed to counteract recent literary developments through legal channels. This healthy public opinion, moreover, is defined in precisely the terms of male virility and nation that the Vizetelly \& Co. novel prefaces had attempted to establish for their support of print freedom. Coote wants to "rouse the manhood of England to action" and to vanquish the "menace" to "national life" posed by English translations of French novels (351). "Too often," Coote continues, "a lax public opinion" enables the publication of offensive material because the magistrates "hesitate," unsure of their public (351-52). Accordingly, the public has to make a loud noise to ensure that their legal representatives will act swiftly to stop the circulation of ostensibly obscene publications.

"Pernicious Literature" is clearly an effort to harness "a sounder public opinion" (361) on the side of the vigilance societies and to legitimate their own work through an alliance with legal institutions. The pamphlet concludes with excerpts from prominent newspapers supporting the work of the NVA. The Times's comment that "the publication of cheap translations" of Zola's novels is a "grave offence against public morals" (373) is one of the more neutral of the newspaper excerpts included. It is the last excerpt, from the Western Morning News, however, that perhaps should give one pause in the context of the wider debate and the dismantling of alternative publics. While agreeing with the Vizetelly prosecution, this journalist notes that the indictment of Zola is "a comedy" when one considers the broader picture:

The other day the unmarried heroine of a novel was described as having been the reader of the whole of Zola's works, and young ladies in a drawing room will not hesitate in these latter days to talk of realism and naturalism with reference to the latest prurient pages of the seeker after degraded aspects of life. These books, which have been debated in society for years, are now practically prohibited for their obscenity. The comedy of it cannot fail to be appreciated. Fathers and mothers in this latter day have become more tolerant of what shall be introduced into their homes than the judge at the old Bailey as to what may be sold in the streets. (381-82).

The matter is not settled quite so neatly as the NVA might have hoped. A reading public eager to read and debate Zola's novels, composed of the very readers to whom they were perceived to pose the most harm, is already alive and well in English society.

If de Amicus celebrates Zola's novels because they make all other novels appear as if "there were a veil between the reader and the thing described" (vi), and Vizetelly endorses this statement, what does Vizetelly mean when he claims, in an interview in the Pall Mall 
Gazette, that he determined "to issue an unabridged translation of Nana [by Zola], suppressing nothing, and merely throwing a slight veil over those passages to which particular exception was likely to be taken" (cited in National 353)? Is Vizetelly, in his translations, reintroducing the veil removed by Zola? Or is he, rather, producing his own veil in the interview consonant with a contradictory literary field where publishers are tried and convicted for publishing Zola novels in translation at the same time as parents and children discuss such novels freely? The fact that Vizetelly used de Amicus's citation both in the preface to Zola's novel and in the advertisements for other Zola novels, illustrates that he was confident that a public existed for whom such an approach would be welcome. The fact that he, at the same time, reintroduces the veil in a newspaper article with a wide circulation, suggests that he knows the limits of that public. If the 1888 and 1889 trials seemed to replace Vizetelly's "slight veil" with blackout material, the Vizetelly prefaces enable us to trace the different strategies open to the writer concerned to engage and challenge print censorship and prevailing constructions of the reader; in doing so, they make visible the nascent construction of a new reading public in the context of which different limitations of novelistic range and different valuations of the novel were drawn.

\section{Carleton University}

\section{NOTES}

1. See McDonald for an excellent account of the reading public in the $1890 \mathrm{~s}$.

2. See also Nead, Kendrick, Saunders, and Leckie for further discussions of female readers and print regulation.

3. Bourdieu, for example, refers to a political field which "produces an effect of censorship by limiting the universe of political discourse, and thereby the universe of what is politically thinkable" (172). And Butler defines implicit censorship as the "implicit operations of power that rule out in unspoken ways what will remain unspeakable" (130).

4. Hunter, Saunders, and Williamson describe the tension between law or legal censorship and regulation (in Foucault's sense) or what they call "diverse regulatory currents" (85).

5. Certain structural aspects of print production and circulation created the same outcome without having to be specifically stated. Works in foreign languages, for example, were less accessible to women and were, therefore, structurally restricted to "cultivated" readers. Similarly, expensive editions were less readily available to wide readerships. Kendrick discusses such cultural constraints in the context of pornography in The Secret Museum.

6. Poovey discusses the rise of the cultural authority of the novel reviewer in "Forgotten Writers, Neglected Histories."

7. Another frequently used strategy was to turn the terms of the debate against the pro-censorship critics. Following their own logic, if they found a work problematic it was only a reflection of their own corrupted imagination. Wilde adopts this strategy (as well as many others) when he claims, in the preface to The Picture of Dorian Gray, that "Those who find ugly meanings in beautiful things are corrupt without being charming" (41).

8. These strategies will be powerfully asserted in the 1890s in the context of aestheticism. Wilde's conclusion to his Dorian Gray preface is perhaps best known in this context: "All art is quite useless" (42).

9. In 1884, confronted by his inability to determine who his audience is, George Moore appeals to Mudie: "I don't know who your customers are.... I want something more definite" ("New" 31). 
10. While Flint focuses on representations of readers, she is interested in establishing connections between these representations and real reading practices. I am interested, by contrast, in the ideological work performed by such representations in the specific context of print censorship. There are several useful reviews of approaches to reading: in Cultures of Print Hall distinguishes between six different approaches to reading in American criticism: reading as an aspect of intellectual history; reading as an aspect of popular culture; reading as "represented" in texts; gender and reading: the "resisting" reader; the reader as appropriator; and was there a "reading revolution"? The introduction to Bennett's Readers and Reading also provides an overview of critical approaches. And Darnton suggests five possible routes that a critic interested in the history of reading might take in "First Steps Toward a History of Reading."

11. Many English writers made similar claims in the period. George Gissing, for example, commented that Workers in the Dawn "is not a book for women and children, but for thinking and struggling men" (cited in Griest 137). Earlier Wilkie Collins had claimed, "My story is not addressed to young people exclusively - it is addressed to readers in general. I do not accept young people as the court of appeal in English literature," Charles Reade noted that his work was "not adapted to the narrow minds of bread-and-butter misses," and George Meredith claimed that if "novels and poems are to be written for young women only, I must learn the art afresh" (cited in Griest 138). In 1863 Caroline Norton maintained that her novel, Lost and Saved, was not written for the young female reader and that the content of the novel had not been delimited accordingly ("Letter" 8). And Justin MacCarthy, in one of the best responses to print censorship in the period, argued that to "condemn such a book [Lost and Saved] out of hand because it was not pretty reading for school-girls, is like condemning Mill's 'Political Economy' because it cannot be converted into nursery rhymes" (41).

12. One of the interesting aspects of studying prefaces is recovering a publishing history that might otherwise be lost for books in which only one or two editions of the novel may include a preface that is, in subsequent editions, dropped or altered.

13. Gautier's preface to Madmoiselle de Maupin and Wilde's preface to The Picture of Dorian Gray are good examples of this sort of preface.

14. De Amicus continues on to link the novel, nevertheless, with "an odour not altogether agreeable." Similarly, in his review of Nana, James writers that Nana is not "pervaded by that ferociously bad smell which blows through L'Assommoir like an emanation from an open drain" (866).

15. It is interesting to note that L'Assommoir was censored when it first came out in serial form in France. James provides an account of the case in his 1903 overview of Zola's works (881-82).

16. I am indebted to Anthony Cummins for providing me with this preface.

17. He thus slightly changes his earlier formulation of an eighteen-year old daughter to a sixteen-year old sister here.

18. Here Moore repeats, as he so often did, a point made in his earlier Pall Mall Gazette article on censorship: "Whether others will follow my example, whether others will see as I see that the literary battle of our time lies not between the romantic and realistic schools of fiction, but for freedom from the illiterate censorship of a librarian, the next few years will most assuredly decide" (32). Both of these passages are likely in dialogue with de Goncourt's preface to Les Freres Zemganno (1879) in which he discusses when "the great battle which will decide the victory of realism, of naturalism" will be decided (244).

\section{WORKS CITED}

Bennett Andrew, ed. Readers and Reading. London: Longman, 1995.

Bourdieu, Pierre. Language and Symbolic Power. Trans. Gino Raymond and Matthew Adamson. Cambridge: Harvard UP, 1991.

Butler, Judith. Excitable Speech: A Politics of the Performative. New York: Routledge, 1997. 
Collins, Wilkie. "The Unknown Public." My Miscellanies. 1859. London: Chatto, 1885.

Darnton, Robert. "First Steps Toward a History of Reading." The Kiss of Lamourette: Reflections in Cultural History. London: Faber, 1990. 154-90.

Daudet, Alphonse. Preface. Sappho: Parisian Manners. London: Vizetelly, 1885.

De Amicus, Edmondo. Preface. The Assommoir. By Emile Zola. London: Vizetelly, 1884. v-xiii.

Derrida, Jacques. Dissemination. Trans. Barbara Johnson. Chicago: U of Chicago P, 1981.

Flint, Kate. The Woman Reader, 1836-1914. Oxford: Oxford UP, 1993.

Frierson, William C. The English Novel in Transition, 1885-1940. Norman: U of Oklahoma P, 1942.

Gautier, Théophile. Preface. Mademoiselle de Maupin. Trans. Joanna Richardson. Harmondsworth: Penguin, 1981. 19-53.

Genette, Gerard. Paratexts: Thresholds of Interpretation. Trans. Jane E. Lewin. Cambridge: Cambridge UP, 1997.

Goncourt, Edmond de. Preface. Les Freres Zemganno. Documents of Modern Literary Realism. Ed. George J. Becker. Princeton: Princeton UP, 1963. 244-46.

Grierson, Herbert J. C. and Sandys Wason. Eds. The Personal Note or First and Last Words from Prefaces, Introductions, Dedications, Epilogues. London: Chatto, 1946.

Griest, Guinevere L. Mudie's Circulating Library and the Victorian Novel. Bloomington: Indiana UP, 1970.

Hall, David D. Cultures of Print: Essays in the History of the Book. Amherst: U of Mass P, 1996.

Hunter, Ian, David Saunders and Dugald Williamson. On Pornography. London: Macmillan, 1992.

James, Henry. Rev. of Nana. Henry James. Literary Criticism: French Writers, Other European Writers, The Prefaces to the New York Edition. Ed. Leon Edel. New York: Library of America, 1984. 864-70.

Keats, John. The Letters of John Keats, 1814-1821. Ed. Hyder Edward Rollins. Vol. 1. Cambridge: Harvard UP, 1958.

Kendrick, Walter. The Secret Museum: Pornography in Modern Culture. New York: Viking, 1987.

Klancher, Jon. The Making of English Reading Audiences, 1790-1832. Madison: U of Wisconsin P, 1987.

Law Reports. "Regina v. Hicklin." Queen's Bench Cases. Vol. 3. London: William Clowes, 1867-68. 368-79.

Leckie, Barbara. Culture and Adultery: The Novel, the Newspaper, and the Law, 1857-1914. Philadelphia: U of Penn P, 1999.

"Lost and Saved." Rev. The Illustrated London News (7 June 1863): 4.

MacCarthy, Justin. "Novels with a Purpose." Westminster Review 82 (1864): 24-49.

Macksey, Richard. "Foreword." Paratexts: Thresholds of Interpretation. By Gerard Genette. Trans. Jane E. Lewin. Cambridge: Cambridge UP, 1997. xi-xxii.

McDonald, Peter D. British Literary Culture and Publishing Practice, 1880-1914. Cambridge: Cambridge UP, 1997.

Marx-Aveling, Eleanor. Preface. Madame Bovary. By Gustave Flaubert. Trans. Eleanor Marx-Aveling. London: Vizetelly, 1886.

Mill, John Stuart. On Liberty. 1859. London: Norton, 1975.

Moore, George. "Literature at Nurse, or Circulating Morals." 1885. Literature at Nurse, or Circulating Morals: A Polemic on Victorian Censorship. Ed. Pierre Coustillas. Hassocks: Harvester, 1976. 2-22.

-“A New Censorship of Literature." 1884. Literature at Nurse, or Circulating Morals: A Polemic on Victorian Censorship. Ed. Pierre Coustillas. Hassocks: Harvester, 1976. 27-32.

—. Preface. A Mummer's Wife. London: Vizetelly, 1886.

—. Preface. Piping Hot! By Emile Zola. London: Vizetelly, 1887.

National Vigilance Association. "Pernicious Literature." Documents of Modern Literary Realism. Ed. George J. Becker. Princeton: Princeton UP, 1963. 350-82.

Nead, Lynda. Myths of Sexuality: Representations of Women in Victorian Britain. London: Blackwell, 1988. Norton, Caroline. Letter. Times [London] 28 Jan. 1857: 8.

Poovey, Mary. "Forgotten Writers, Neglected Histories: Charles Reade and the Nineteenth-Century Transformation of the British Literary Field." ELH 71.2 (2004): 433-53. 
Saunders, David. "Victorian Obscenity Law: Negative Censorship or Positive Administration." Writing and Censorship in Britain. Ed. Paul Hyland and Neil Sammells. London: Routledge, 1992. 154-70.

"The Trial of Madame Bovary." Trans. Evelyn Gendel. Madame Bovary. By Gustave Flaubert. New York: Signet, 1964. 325-403.

Trollope, Anthony. "Novel Reading." Nineteenth Century (1879): 79-91.

Warner, Michael. Publics and Counterpublics. New York: Zone, 2005.

Wilde, Oscar. Preface. The Picture of Dorian Gray. Peterborough: Broadview, 1998. 41-42. 